\title{
SZERSZÁM AZ EGYENESFOGÚ EVOLVENSKEREKEK MEGMUNKÁLÁSÁRA HOSSZIRÁNYÚ HORDÓSÍTÁSSAL.
}

\author{
Janka Zoltán Máté Márton
}

A fogaskerekek fogainak megmunkálása a jobb hordkép elérése érdekében az elméleti evolvensprofiltól eltérõen történik. A gyakorlatban ezt a fogalak úgynevezett hordósításával érik el, mely a fogprofil módositásával (fej- illetve láblenyeséssel ) történik, vagy pedig a fog alkotógörbéje görbületi sugarának változtatásával. Ez utóbbi módszer elōnyei különösképpen a kapcsolószekrények felépitésében alkalmazott fogaskerekek esetében tünnek ki. Ellentétben a fogalakmódositással, a hosszanti hordósítás megvalósitása körülményes.

A jelen dolgozatban a hosszanti hordósitás egyszerü megvalósitását eredményezõ szerszám kerül bemutatásra, mely a fogaskereket lefejtéssel munkálja meg. İgy elérhetõ egy viszonylag egyszerü technológiai berendezés alkalmazásával a célul kitűzött fogalakmódosítás.

\section{A szerszám müködési elve.}

Jelen esetben a javasolt szerszámnak egyszerre kell biztositania mind a hordositást, mind pedig a fogaskerékkel való kapcsolódást. Az elöbbi a szerszám geometriai sajátosságainak, az utóbbi pedig a mozgó egyenes elvén történő evolvensképzés szimulációjának eredménye. A szerszám állandótengelyü és szögsebességü forgómozgásának következményeként az élek által burkolt származtatófelület a megmunkálandó kerék tengelyére meröleges szimmetriasikban egy állandó sebességgel mozgó lécprofilt generál. A megmunkálandó kerék ezzel a futóprofillal kapcsol.

A futó lécprofil akkor képzödik, ha a származtatófelület egy archimédeszi spirálra képzett vonalfelület. Ezzel viszont a kapcsolás csak az említett szimmetriasíkban tökéletes. Egy ezzel párhuzamos sikban a szerszám és a darab között csúszás lép fel, mely az archimédeszi vezérgörbe alakjából kifolyoóag történö lécprofil-irányváltozás következménye.Emiatt párhuzamos síkokban a szerszám többet vág le a fogból.Ezért a fog hosszirányban a szélek felé elvékonyodó lesz. Ez megfelel a hosszirányú hordósitás által elöidézett fogalakváltozásnak, mely a hordképet a fog középső részére lokalizálja.Ennek következtében a hajtás kevésbé lesz érzékeny a szerelési pontatlanságokra. 
kezdeti helyzetẻhez képest $\varphi 2$ szöggel fordul. Mivel aszerszám fogai egyetlen spirál mentén helyezkednek el, a $\varphi 1$ és $\varphi 2$ szögek között az alábbi kapcsolat áll fenn:

$$
\varphi_{1}=\mathrm{z} \cdot \varphi_{2}
$$

ahol $\mathbf{z}$ a megmunkálandó kerék fogszáma.

Az S1 és S2 koordinátarendszerek közötti kapcsolat az alábbi mátrixszorzattal fejezhetö ki:

$$
M_{21}=\left\|\begin{array}{cccc}
-\sin \left(\varphi_{2}-\varepsilon\right) & 0 & \cos \left(\varphi_{2}-\varepsilon\right) & a_{2} \\
-\cos \left(\varphi_{2}-\varepsilon\right) & 0 & -\sin \left(\varphi_{2}-\varepsilon\right) & b_{2} \\
0 & -1 & 0 & 0 \\
0 & 0 & 0 & 1
\end{array}\right\| \times\left\|\begin{array}{cccc}
\cos \varphi_{1} & -\sin \varphi_{1} & 0 & 0 \\
\sin \varphi_{1} & \cos \varphi_{1} & 0 & 0 \\
0 & 0 & 1 & 0 \\
0 & 0 & 0 & 1
\end{array}\right\|
$$

ahol :

$$
\left\{\begin{array}{l}
a_{2}=R \cdot \cos \left(\varphi_{2}-\varepsilon\right)+R_{0} \cdot \sin \left(\varphi_{2}-\varepsilon\right) \\
b_{2}=R_{0} \cdot \cos \left(\varphi_{2}-\varepsilon\right)-R \cdot \sin \left(\varphi_{2}-\varepsilon\right) \\
\varepsilon=\operatorname{inv}_{0}+\operatorname{arctg} \frac{a \cdot \cos ^{2} \alpha_{0}}{R+a \cdot \sin \alpha_{0} \cdot \cos \alpha_{0}}
\end{array}\right.
$$

Az S2 rendszerben keletkezö felületsereg egyenleteit az alábbi mátrixszorzatból kapjuk:

$$
\mathbf{r}_{2}=\mathbf{M}_{21} \times \mathbf{r}_{1}
$$

A $p 1, \theta$ és u paraméterek közötti kapcsolat implicit függvényét a kinematikai módszer [1] alkalmazásával keressük. A 3. sz. ábra alapján az S1 szerszámrendszerhez viszonyított relativ elmozdulási sebesség összetevői a következöek:

$$
v_{1}^{(21)}=\left\|\begin{array}{c}
-\omega_{2}\left(z_{1}+R\right) \cdot \cos \varphi_{1}+\omega_{1} y_{1} \\
\omega_{2}\left(z_{1}+R\right) \cdot \sin \varphi_{1}-\omega_{1} x_{1} \\
\omega_{2}\left(x_{1} \cos \varphi_{1}-y_{1} \sin \varphi_{1}\right)-\omega_{2} R_{0}
\end{array}\right\|
$$

A szerszám és a darab kapcsolódási egyenlete az S1 rendszerben a legegyszerübb, mivel a származtatófelület normálvektora a (3) egyenletekböl könnyen felírható.

$$
\stackrel{r}{n_{1}} \cdot v_{1}^{(21)}=\left\|\begin{array}{c}
-(\sin \theta+P \cdot \cos \theta) \\
\cos \theta-P \cdot \sin \theta \\
-\operatorname{tg} \alpha_{0} \cdot P
\end{array}\right\| \cdot v_{1}^{(21)}=0
$$

ahol

$$
\mathbf{P}(\mathbf{u}, \theta)=\frac{2 \mathbf{C}_{\mathrm{n}}}{\mathrm{m}}-\frac{2 \sin \alpha_{\tilde{b}}}{\mathrm{~m}} \cdot \mathbf{u}+\theta
$$

A (9) skaláregyenlet megoldható $\varphi 1-r e$, ami az alábbi $\varphi l=\varphi l(u, \theta)$ függvényt eredményezi: 


\section{A származtató felület egyenletei.}

A származtatófelület alkotógörbéje egyenes, mely a lécprofilnak felel meg. Egyenletei az Oxlylzl rendszerben ( 1 .ábra) a következöek:

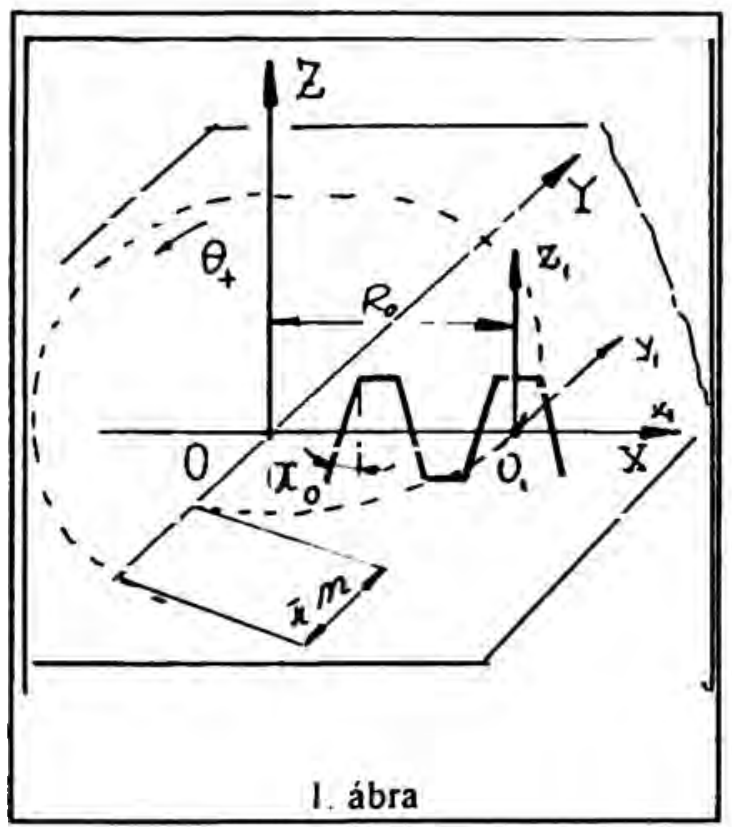

$$
\left\{\begin{array}{l}
x 1=a-u \cdot \cos \alpha_{0} \\
y 1=0 \\
z 1=u \cdot \cos \alpha_{n}
\end{array}\right.
$$

$\mathrm{Az}$ alkotógörbének az archimédeszi vezérgörbe mentén való elmozdulása matemetikailag az oxly|z| rendszernek az oxyz- hez képest való elmozdulásával fejezhetö ki, melynek mátrixa:

$$
\mid \begin{array}{cccc}
\cos \theta & -\sin \theta & 0 & \left(\mathbf{R}_{0}+\frac{\mathbf{m}}{2} \cdot \theta\right) \cdot \cos \theta \\
\sin \theta & \cos \theta & 0 & \left(\mathbf{R}_{0}+\frac{m}{2} \cdot \theta\right) \cdot \sin \theta \\
0 & 0 & 1 & 0 \\
0 & 0 & 0 & 1
\end{array} \|
$$

ahol $\mathbf{R}_{\mathbf{0}}$ a spirál indulósugara, $\mathbf{m}$ a modul és a a fogasléc osztóvonalon mért negyedlépése. Az (1) és (2) -böl a származtatófelület parametrikus egyenletei u és 0 paraméterekben a következőek:

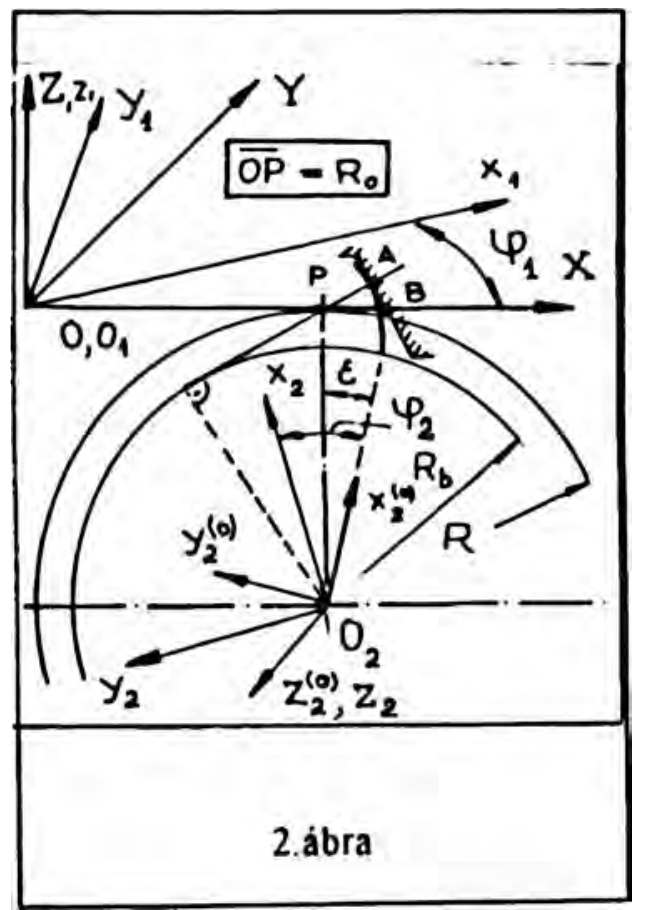

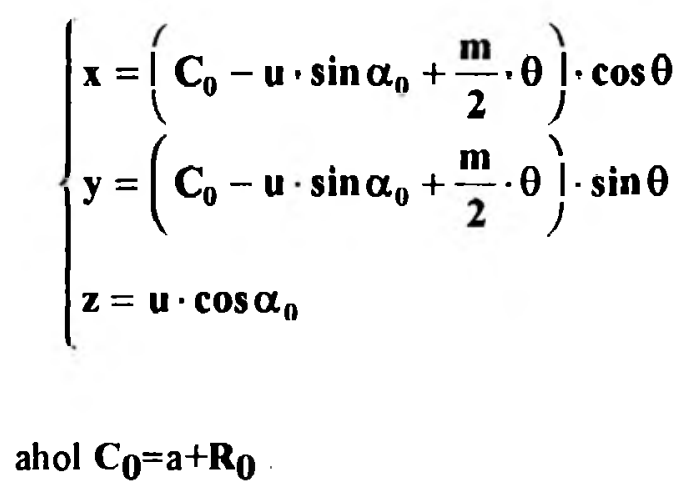

\section{A megmunkált fogfeluilet egyenletei.}

A darab fogfelülete a szerszám forgómozgása következtében a darabhoz kötött rendszerben keletkező származtató felületsereg burkoló felülete.Aszerszám és a darab viszonylagos elmozdulása matematikailag ahozzájuk kötött koordinátarendszerek helyzetével fejezhetö ki.Ez,illetve az elmozdulások a 2sz. ábrán láthatoak. A szerszámhoz kötött S1 $=0|x| y \mid z l$ rendszer az álló $S=O X Y Z$ rendszerhez képest $\varphi \mid$ szöggel fordul el. A darabhoz kötött $S 2=x 2 y 2 z 2$ rendszer a 


$$
\begin{aligned}
& P_{1}^{(1, n)}= \pm \arccos \frac{\left(z_{2}^{m} \mid K_{0} \lg x_{0}\right)}{\sqrt{\left[P(u, 0]^{2} \cdot\left[m_{2}^{m} \operatorname{tg} \alpha_{8} P(u, 0)-\left(z_{1}+R\right)\right]^{2}+\left(z_{1}+R\right)^{2}\right.}}-(0+\Lambda) \\
& \Lambda=\operatorname{arctg} \frac{z_{1}+R}{P(u, 0)\left[\frac{m}{2} \operatorname{tg}\left(x_{0} P(u, 0)-\left(z_{1}+R\right)\right]\right.}
\end{aligned}
$$

A fogfelület parametrikus egyenleteit a (11) - nek a (7)- be való behelyettesıtésével kapjuk.

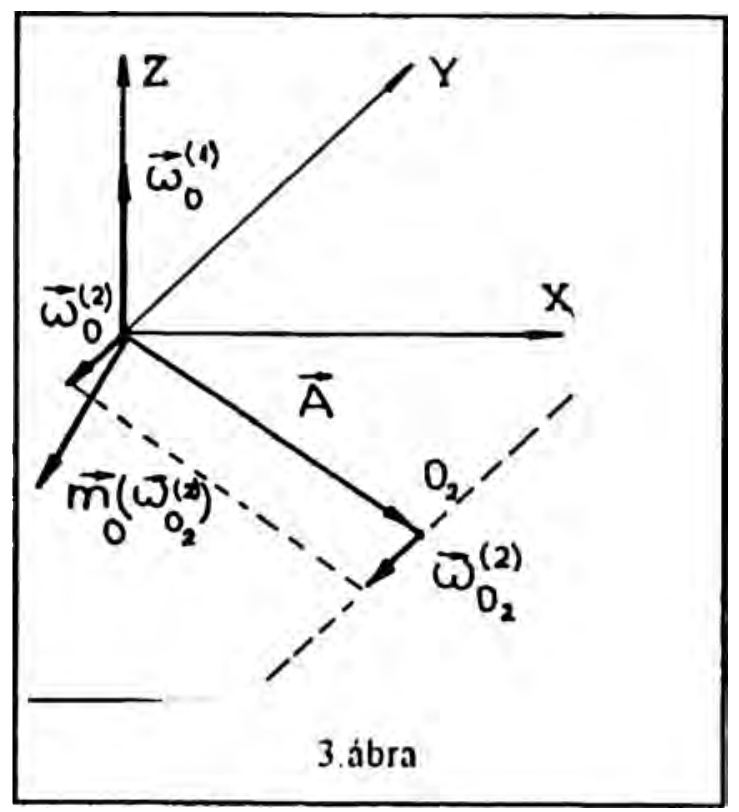

\section{IRODALOM}

1. LITVIN, F., L., A fogaskerékkapcsolás elmélete, Müszaki Könyvkiadó, Budapest, 1972.

Janka Zoltán egyetemi hallgató

Máté Márton egyetemi adjunktus

Marosvásárhelyi Egyetem , N. lorga u., 1. sz., 4300 Marosvásárhely 